\title{
Photochemistry of biogenic emissions over the Amazon forest
}

\section{Citation}

Jacob, Daniel J., and Steven C. Wofsy. 1988. "Photochemistry of Biogenic Emissions over the Amazon Forest." Journal of Geophysical Research 93 (D2): 1477. doi:10.1029/jd093id02p01477.

\section{Published Version}

doi:10.1029/JD093iD02p01477

\section{Permanent link}

http://nrs.harvard.edu/urn-3:HUL.InstRepos:14121764

\section{Terms of Use}

This article was downloaded from Harvard University's DASH repository, and is made available under the terms and conditions applicable to Other Posted Material, as set forth at http:// nrs.harvard.edu/urn-3:HUL.InstRepos:dash.current.terms-of-use\#LAA

\section{Share Your Story}

The Harvard community has made this article openly available.

Please share how this access benefits you. Submit a story.

\section{Accessibility}




\title{
Photochemistry of Biogenic Emissions Over the Amazon Forest
}

\author{
Daniel J. Jacob and Steven C. Wofsy
}

Earth and Planetary Sciences, Division of Applied Science, Harvard University, Cambridge, Massachusetts

\begin{abstract}
The boundary layer chemistry over the Amazon forest during the dry season is simulated with a photochemical model. Results are in good agreement with measurements of isoprene, NO, ozone, and organic acids. Photochemical reactions of biogenic isoprene and $\mathrm{NO}_{x}$ can supply most of the ozone observed in the boundary layer. Production of ozone is very sensitive to the availability of $\mathrm{NO}_{x}$, but is insensitive to the isoprene source strength. High concentrations of total odd nitrogen $\left(\mathrm{NO}_{y}\right)$ are predicted for the planetary boundary layer, about $1 \mathrm{ppb}$ in the mixed layer and $0.75 \mathrm{ppb}$ in the convective cloud layer. Most of the odd nitrogen $(\approx 70 \%)$ is present as PAN-type species, which are removed by dry deposition to the forest. The observed daytime variations of isoprene are explained by a strong dependence of the isoprene emission flux on sun angle. Nighttime losses of isoprene exceed rates of reaction with $\mathrm{NO}_{3}$ and $\mathrm{O}_{3}$ and appear to reflect dry-deposition processes. The 24-hour averaged isoprene emission flux is calculated to be $38 \mathrm{mg} \mathrm{m} \mathrm{m}^{-2} \cdot \mathrm{d}^{-1}$. Photooxidation of isoprene could account for a large fraction of the $\mathrm{CO}$ enrichment observed in the boundary layer under unpolluted conditions and could constitute an important atmospheric source of formic acid, methacrylic acid, and pyruvic acid.
\end{abstract}

\section{InTRODUCTION}

The Amazon Boundary Layer Experiment (ABLE 2A) [Harris et al., this issue] provided a detailed survey of atmospheric composition over the central Amazon forest during the dry season. High concentrations of isoprene, a hydrocarbon emitted by vegetation, were measured [Zimmerman et al., this issue; Rasmussen and Khalil, this issue]. The forest soil was found to be a strong source of NO [Kaplan et al., this issue]. In this paper we examine some implications of these findings.

In the absence of biomass burning, ozone concentrations over the Amazon Basin are lower in the boundary layer than in the free troposphere [Delany et al., 1985; Crutzen et al., 1985; Gregory et al., this issue]. During ABLE 2A, Gregory et al. [this issue] measured $\mathrm{O}_{3}$ concentrations of $0-25 \mathrm{ppb}$ and $30-40 \mathrm{ppb}$ in the boundary layer and in the free troposphere, respectively. Delany et al. [1985] report similar values. On the basis of the data from Delany et al. [1985], Crutzen et al. [1985] have argued that $\mathrm{O}_{3}$ in the boundary layer is supplied by downward transport from the free troposphere and is removed by deposition to the canopy and by reaction with biogenic hydrocarbons. This theory implies that photochemical production of $\mathrm{O}_{3}$ in the boundary layer is slow relative to mass exchange across the trade wind inversion which separates the boundary layer from the free troposphere.

Model investigations by Lurmann et al. [1983] indicate that $\mathrm{O}_{3}$ production from biogenic emissions is relatively slow in the rural United States. In some cases, photochemical reactions may even consume $\mathrm{O}_{3}$ because of the scarcity of $\mathrm{NO}_{x}$, a result in harmony with the theory of Crutzen et al. [1985]. However, soils in the Amazon forest are much stronger sources of NO than soils at mid-latitudes [Galbally, 1985; Kaplan et al., this issue]. Observed concentrations of NO in the mixed layer during ABLE $2 \mathrm{~A}$ were in the range 20-65 parts per trillion (ppt) [Torres and Buchan, this issue], sufficient for significant production of $\mathrm{O}_{3}$. As discussed further later, NO emissions from soils play an important role in the photochemistry over the Amazon forest. The photochemistry of $\mathrm{NO}_{x}$ radicals is moderated by conversion to PAN-type species, which are predicted to be the dominant form of atmo-

Copyright 1988 by the American Geophysical Union.

Paper number 7D0554.

0148-0227/88/007D-0554\$05.00 spheric odd nitrogen. We argue that the $\mathrm{O}_{3}$ concentrations observed in the boundary layer during ABLE $2 \mathrm{~A}$ can be explained largely on the basis of photochemical productior. within the boundary layer, driven by biogenic isoprene and $\mathrm{NO}_{x}$.

Photochemical decomposition of isoprene produces a number of oxygenated hydrocarbon species [Lloyd et al., 1983], including organic acids. These are of particular interest, since they constitute the major component of rainwater acidity over the Amazon Basin [Andreae et al., this issue (a)]. We propose that formic acid, methacrylic acid, and pyruvic acid can be produced in large quantities from decomposition of isoprene. Model predictions for formic and pyruvic acids are consistent with concentrations measured during ABLE 2A [Andreae et al., 1987, this issue (a)].

Most of the carbon in atmospheric isoprene is eventually oxidized to CO [Zimmerman et al., 1978]. Elevated concentrations of $\mathrm{CO}$ were often observed over the Amazon forest during ABLE $2 \mathrm{~A}$ and were usually associated with pollution plumes from biomass burning or from the urban environs of Manaus [Andreae et al., this issue (b)]. However, even in the absence of eyident pollution, $\mathrm{CO}$ concentrations in the boundary layer were observed to be $10-30 \mathrm{ppb}$ higher than in the free troposphere [Sachse et al., this issue]. This enrichment of $\mathrm{CO}$ may be attributed to primary emissions from vegetation, to photooxidation of biogenic hydrocarbons, or to long-range transport of pollution. We show below that the photochemical degradation of isoprene can account for 10-20 ppb enhancement of $\mathrm{CO}$ in the boundary layer relative to the free troposphere.

Our discussion will be based on a photochemical model using the detailed chemical mechanism of Lurmann et al., [1986], modified as described in section 2. The dynamics of the boundary layer are simulated with a simple scheme described in section 3 , intended to capture the main features of vertical transport in the lower troposphere over the Amazon forest. We then discuss model results, focusing on isoprene and $\mathrm{CO}$ in section 4, odd nitrogen in Section 5, ozone in section 6 , and organic acids in section 7 .

\section{Chemical Mechanism}

The gas-phase photochemistry of isoprene and $\mathrm{NO}_{x}$ is simulated using a suite of chemical reactions adapted from $L u r-$ 
mann et al. [1986]. Isoprene reacts with $\mathrm{OH}, \mathrm{O}_{3}$, and $\mathrm{NO}_{3}$ to produce methylvinylketone and methacrolein. These two species react further with $\mathrm{OH}, \mathrm{O}_{3}$, and $\mathrm{NO}_{3}$, producing a number of carbonyl compounds. The rate constant for the isoprene $+\mathrm{OH}$ reaction has been updated to $2.5 \times$ $10^{-11} \exp (409 / T) \mathrm{cm}^{3}$ molecule $\mathrm{s}^{-1}$, following the recommendation by Atkinson [1986].

The $\mathrm{RO}_{2}$ radicals produced from photooxidation of hydrocarbons play a key role in atmospheric photochemistry. When $\mathrm{NO}$ levels are high, $\mathrm{RO}_{2}$ radicals react mainly with $\mathrm{NO}$, resulting in ozone formation. When little $\mathrm{NO}$ is available, $\mathrm{RO}_{2}$ may react instead with $\mathrm{HO}_{2}$, consuming odd hydrogen. In general, the Lurmann et al. [1986] mechanism allows $\mathrm{RO}_{2}$ radicals to react with both $\mathrm{NO}$ and $\mathrm{HO}_{2}$. However, many reactions in the mechanism are represented by global stoichiometric expressions in which the $\mathrm{RO}_{2}$ radicals are treated as transient intermediates assumed to react instantaneously with NO. These stoichiometric expressions include zero-order loss terms for NO and are valid only for high NO concentrations. When NO concentrations are of order 10-100 ppt, as over the Amazon forest [Torres and Buchan, this issue], use of the original Lurmann et al. [1986] mechanism is inappropriate and would lead to serious errors.

Therefore we modified the Lurmann et al. [1986] mechanism to include an explicit description of $\mathrm{RO}_{2}+\mathrm{NO}$ and $\mathrm{RO}_{2}$ $+\mathrm{HO}_{2}$ reactions for all intermediate $\mathrm{RO}_{2}$ radicals produced by photooxidation of hydrocarbons. The rate constants selected for these reactions are $4.2 \times 10^{-12} \exp (180 / T) \mathrm{cm}^{3}$ molecule ${ }^{-1} \mathrm{~s}^{-1}$ and $3 \times 10^{-12} \mathrm{~cm}^{3}$ molecule ${ }^{-1} \mathrm{~s}^{-1}$, respectively, in accord with the values assumed by Lurmann et al. [1986] for such reactions. The $\mathrm{RO}_{2}+\mathrm{NO}$ reactions are assumed to give products consistent with the global stoichiometric expressions of the original mechanism. The $\mathrm{RO}_{2}$ $+\mathrm{HO}_{2}$ reactions produce organic peroxides, which are assumed to be removed by reaction with $\mathrm{OH}\left(k=1 \times 10^{-11}\right.$ $\mathrm{cm}^{3}$ molecule $\left.\mathrm{s}^{-1} \mathrm{~s}^{-1}\right)$, by photolysis $\left(k=5 \times 10^{-4} J_{\mathrm{NO}_{2}}\right)$, and by deposition to the canopy.

Formic acid is produced in the gas phase by reaction of $\mathrm{CH}_{2} \mathrm{O}$ with $\mathrm{HO}_{2}$ [Su et al., 1979], and by reactions of alkenes with $\mathrm{O}_{3}$ [Atkinson and Lloyd, 1984]. The reaction $\mathrm{CH}_{2} \mathrm{O}$ $+\mathrm{HO}_{2}$ produces the intermediate $\mathrm{O}_{2} \mathrm{CH}_{2} \mathrm{OH}$, which may either decompose back to the original reactants or react with $\mathrm{NO}$ or $\mathrm{HO}_{2}$ to give $\mathrm{HCOOH}$ [Su et al., 1979; Atkinson and Lloyd, 1984]. Lurmann et al. [1986] assume that the $\mathrm{CH}_{2} \mathrm{O}$ $+\mathrm{HO}_{2}$ reaction produces $\mathrm{HCOOH}$ with a yield of unity, i.e., they ignore the back reaction of $\mathrm{O}_{2} \mathrm{CH}_{2} \mathrm{OH}$. However, this assumption may be justified only for $\mathrm{NO}$ concentrations in excess of $10 \mathrm{ppb}$, when the reaction $\mathrm{O}_{2} \mathrm{CH}_{2} \mathrm{OH}+\mathrm{NO}$ is sufficiently fast that the back reaction may be neglected [Atkinson and Lloyd, 1984]. At lower NO concentrations the $\mathrm{HCOOH}$ yield is much less than unity, so that the Lurmann et al. [1986] mechanism would produce excessive amounts of $\mathrm{HCOOH}$. We have included the back reaction of $\mathrm{O}_{2} \mathrm{CH}_{2} \mathrm{OH}$ in our calculations and find that the $\mathrm{CH}_{2} \mathrm{O}+\mathrm{HO}_{2}$ reaction is a negligible source of $\mathrm{HCOOH}$ at the $\mathrm{NO}$ levels observed over the Amazon forest by Torres and Buchan [this issue].

The main gas-phase source of $\mathrm{HCOOH}$ over the Amazon forest involves decomposition of the Criegee biradical, - $\mathrm{CH}_{2} \mathrm{OO} \cdot$, produced by ozonolysis of isoprene, methylvinylketone, and methacrolein:

$$
\underset{\text { (isoprenc) }}{\mathrm{CH}_{2} \mathrm{CHC}\left(\mathrm{CH}_{3}\right) \mathrm{CH}_{2}}+\mathrm{O}_{3} \rightarrow 0.5 \mathrm{CH}_{2} \mathrm{O}
$$

$$
+\underset{\text { (methylvinylketone) }}{0.2 \mathrm{CH}_{2} \mathrm{CHC}(\mathrm{O}) \mathrm{CH}_{3}}
$$

$$
\begin{aligned}
& +\underset{\text { (methacrolein) }}{0.3 \mathrm{CH}_{2} \mathrm{C}\left(\mathrm{CH}_{3}\right) \mathrm{CHO}}+0.2 \cdot \mathrm{CH}_{2} \mathrm{OO} \cdot+0.06 \mathrm{HO}_{2} \\
& +\underset{(\text { MVKO })}{0.2 \mathrm{CH}_{2} \mathrm{CHC}(\mathrm{OO}) \mathrm{CH}_{3}}+\underset{(\mathrm{MAOO})}{0.3 \mathrm{CH}_{2} \mathrm{C}\left(\mathrm{CH}_{3}\right) \mathrm{CHOO}}
\end{aligned}
$$

$\mathrm{CH}_{2} \mathrm{CHC}(\mathrm{O}) \mathrm{CH}_{3}+\mathrm{O}_{3} \rightarrow 0.5 \mathrm{CH}_{2} \mathrm{O}+0.2 \cdot \mathrm{CH}_{2} \mathrm{OO}$. (methylvinylketone)

$$
\begin{aligned}
+0.21 \mathrm{HO}_{2} & +0.2 \mathrm{CH}_{3} \mathrm{C}(\mathrm{O}) \dot{\mathrm{C}} \mathrm{HOO}+0.15 \mathrm{CH}_{3} \mathrm{CHO} \\
& +0.5 \mathrm{CH}_{3} \mathrm{C}(\mathrm{O}) \mathrm{CHO}+0.15 \mathrm{CH}_{3} \mathrm{C}(\mathrm{O}) \mathrm{O}_{2}
\end{aligned}
$$

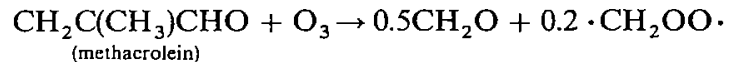

$$
+\underset{\text { (MGLY) }}{0.2 \mathrm{CH}_{3} \mathrm{C}(\mathrm{OO}) \mathrm{CHO}}
$$

Reaction with water vapor is the main sink for $\cdot \mathrm{CH}_{2} \mathrm{OO}$. [Atkinson and Lloyd, 1984], and produces $\mathrm{HCOOH}$ with a yield of unity [Hatakeyama et al., 1981]:

$$
\text { - } \mathrm{CH}_{2} \mathrm{OO} \cdot+\mathrm{H}_{2} \mathrm{O} \rightarrow \mathrm{HCOOH}+\mathrm{H}_{2} \mathrm{O}
$$

The higher Criegee biradicals (MVKO, MAOO, MCRG, and MGLYO) should also be produced by (R1)-(R3). Lurmann et al. [1986] give MCRG as the biradical produced by (R3); but we expect on mechanistic grounds that MGLYO should be produced instead. Reactions of the higher biradicals have not been measured experimentally and are not included in the Lurmann et al. mechanism. We have proposed [Jacob and Wofsy, 1988] that MCRG and MAOO should react primarily with $\mathrm{H}_{2} \mathrm{O}$, in the same way as $\cdot \mathrm{CH}_{2} \mathrm{OO} \cdot$, to produce pyruvic acid and methacrylic acid, respectively:

$$
\begin{aligned}
& \text { (R5) } \mathrm{CH}_{3} \mathrm{C}(\mathrm{O}) \dot{\mathrm{C}} \mathrm{HOO}+\mathrm{H}_{2} \mathrm{O} \rightarrow \mathrm{CH}_{3} \mathrm{C}(\mathrm{O}) \mathrm{COOH}+\mathrm{H}_{2} \mathrm{O} \\
& \text { (MCRG) (pyruvic acid) } \\
& \underset{\text { (MAOO) }}{\mathrm{CH}_{2} \mathrm{C}\left(\mathrm{CH}_{3}\right) \dot{\mathrm{C}} \mathrm{HOO}}+\underset{\text { (methacrylic acid) }}{\mathrm{H}_{2} \mathrm{O}} \rightarrow \underset{2}{\mathrm{CH}} \underset{2}{\mathrm{C}\left(\mathrm{CH}_{3}\right) \mathrm{COOH}}+\mathrm{H}_{2} \mathrm{O}
\end{aligned}
$$

A rate constant, $k=4 \times 10^{-18} \mathrm{~cm}^{3}$ molecule ${ }^{-1} \mathrm{~s}^{-1}$, has been recommended for (R4) [Atkinson and Lloyd, 1984], and we assume this same rate constant for (R5) and (R6). In the case of the biradicals MGLYO and MVKO, the radical carbon is fully substituted and reaction with water vapor (if it occurs) would not produce a carboxylic acid. We assume here that MGLYO and MVKO decompose to unreactive products.

Formic acid is removed primarily by dry deposition, washout, and aqueous-phase oxidation in clouds [Chameides, 1984; $J a c o b, 1986]$. It does not photolyze [Calvert and Pitts, 1966], and gas-phase reaction with $\mathrm{OH}$ is slow $\left(k=4.6 \times 10^{-13} \mathrm{~cm}^{3}\right.$ molecule $\mathrm{s}^{-1} \mathrm{~s}^{-1}$; Wine et al. [1985]). Pyruvic acid photolyzes in the troposphere on a time scale of a few hours [Grosjean, 1983], by absorption of radiation as wavelengths up to 370 $\mathrm{nm}$ with a quantum yield near unity for dissociation to $\mathrm{CO}_{2}$ [Yamamoto and Back, 1985]. Reaction of pyruvic acid with $\mathrm{OH}$ is slow $\left(k<5 \times 10^{-14} \mathrm{~cm}^{3}\right.$ molecule ${ }^{-1} \mathrm{~s}^{-1}$; Grosjean [1983]). Methacrylic acid does not photolyze at tropospheric wavelengths [Rosenfeld and Weiner, 1983], but it probably reacts rapidly with $\mathrm{OH}$ by addition to the $\mathrm{C}=\mathrm{C}$ bond. We assume that the reaction of $\mathrm{OH}$ with methacrylic acid proceeds with the same rate constant as the reaction of $\mathrm{OH}$ with 2-methyl propene $\left(k=1.2 \times 10^{-11} \exp (500 / T) \mathrm{cm}^{3}\right.$ molecule ${ }^{-1} \mathrm{~s}^{-1} ;$ Atkinson [1986]).

Radiation fields in the photochemical model are calculated 


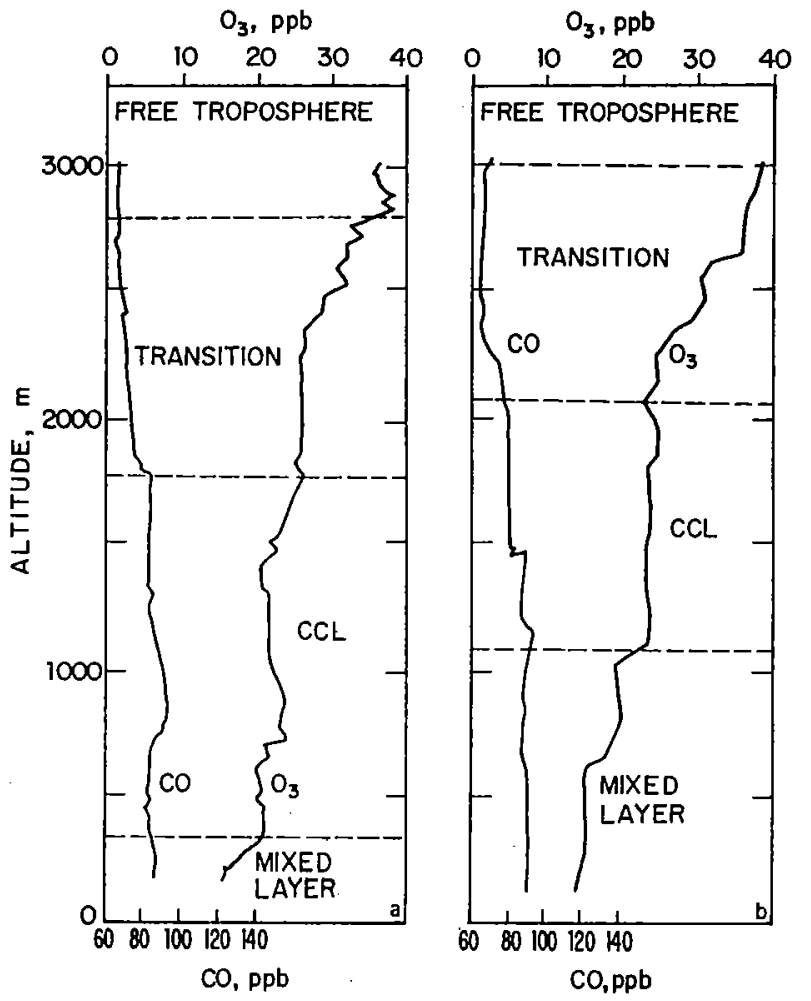

Fig. 1. Vertical profiles of $\mathrm{O}_{3}$ and $\mathrm{CO}$ measured during ABLE 2A flight 5 (July 23; 1985) at (a) 0815 LT and (b) 1045 LT. Data are reproduced from Gregory et al. [this issue] and Sachse et al. [this issue].

for $0^{\circ}$ latitude, a surface albedo of 0.1 , and an $\mathrm{O}_{3}$ column of $5.5 \times 10^{18}$ molecules $\mathrm{cm}^{-2}$ (V. W. J. H. Kirchhoff, E. V. Browell, and G. L. Gregory, Ozone profile measurements in Amazonia, submitted to the Journal of Geophysical Research, 1987, hereafter referted to as Kirchhoff et al., submitted manuscript, 1987). Light extinction by aerosols is assumed to provide 0.1 optical depth at $310 \mathrm{~nm}$ and to vary as the inverse of wavelength [Logan et al., 1981]. Photolysis rates in the mixed layer are calculated for $30 \%$ cloud cover, on the basis of radiation flux measurements by Fitzjarrald et al. [this issue].

\section{Dynamrcal Model}

The vertical structure of the atmosphere over the Amazon Basin was resolved during ABLE $2 \mathrm{~A}$ by aircraft profiles and by frequent soundings using a tethered balloon [Martin et al., this issue]. Measurements included temperature, dew point, and winds [Harriss et al., this issue], and concentrations of aerosols and $\mathrm{O}_{3}$ [Gregory et al., this issue], $\mathrm{CO}$ [Sachse et al., this issue], and $\mathrm{CO}_{2}$ [Wofsy et al., this issue]. It can be con-

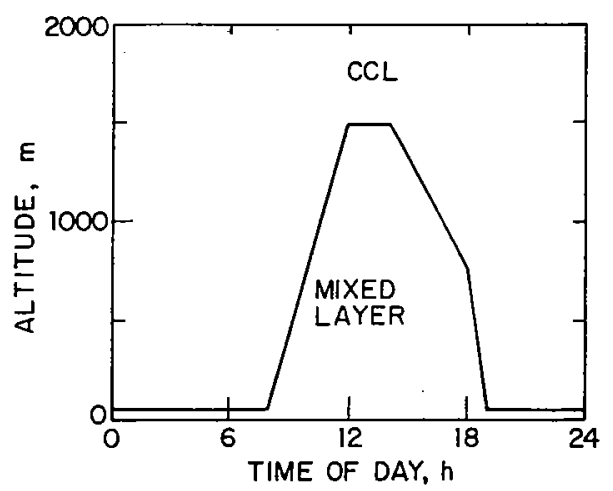

Fig. 2. Height of the mixed layer as a function of time of day. cluded from these data that the air column over the forest is typically divided into three major layers, with boundaries defined by temperature inversions and by sharp concentration gradients for one or more tracers. These layers are (1) the planetary boundary layer (PBL) extending from the top of the canopy up to about $2000 \mathrm{~m}$, (2) a fairly stable transition layer extending from the top of the PBL to the trade wind inversion, and (3) the free troposphere above. Profiles of $\mathrm{O}_{3}$ and $\mathrm{CO}$ from flight 5 (Figure 1) illustrate this vertical structure. The trade wind inversion over the Amazon Basin is based at $2200-3200 \mathrm{~m}$ [Browell et al., this issue]. It is a quasipermanent feature of the synoptic meteorology during the dry season and constitutes a strong barrier to vertical transport.

The vertical profiles of Figure 1 indicate clearly that the PBL, as defined earlier, is not homogeneous. At least two sublayers can usually be identified: the mixed layer and the convective cloud layer (CCL). The depth of the mixed layer is determined by the radiative balance at the top of the canopy and peaks at about $1500 \mathrm{~m}$ in the middle of the day [Martin et al., this issue]. The CCL lies above the mixed layer and is defined by frequent, small-scale cumulus activity in the daytime. Transport from the mixed layer to the CCL is expected to proceed rapidly during the daytime hours, with exchange localized in areas of cloud updrafts and downdrafts. Transport from the CCL to the transition layer above $2000 \mathrm{~m}$ appears to be much slower, as indicated by gradients of trace species. We expect that biogenic gases with lifetimes between 1 and 10 hours should affect significantly the compositions of the mixed layer and the CCL but have a much smaller influence on the air above $2000 \mathrm{~m}$.

On the basis of these observations, we adopt a two-layer dynamical model describing the growth and decay of the mixed layer and the coupling between the mixed layer and the CCL. Mass exchange at the top of the CCL is represented by flux boundary conditions. Mixed layer heights are assumed to follow a diurnal cycle, as shown in Figure 2, which is typical of observations during ABLE 2A [Martin et al., this issue; Wofsy et al., this issue ]. At night, the mixed layer extends to only a few tens of meters above the canopy. Following sunrise, the mixed layer grows rapidly in response to solar heating, at a rate of $10 \mathrm{~cm} \mathrm{~s}^{-1}$ during the midmorning hours. The mixed layer depth peaks at $1500 \mathrm{~m}$ between noon and $1400 \mathrm{LT}$. Cloud formation eventually reduces the positive radiation balance at the top of the canopy [Fitzjarrald et al., this issue], so that the mixed layer decays over the course of the afternoon. At sunset the radiative balance becomes negative (net cooling at canopy top), and the mixed layer decays rapidly to its nighttime depth. The diurnal cycle of temperature (Figure 3 ) is taken from Fitzjarrald et al. [this issue].

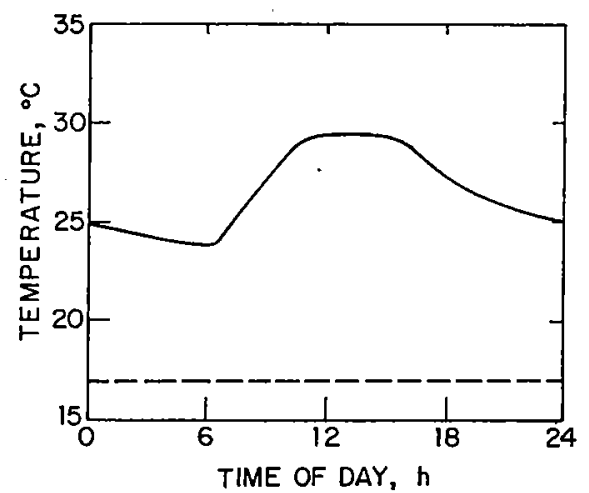

Fig. 3. Diurnal variation of temperature in the mixed layer (solid line) and in the CCL (dashed line). 
Vertical displacement of the mixed layer/CCL inversion during the day results in substantial transfer of mass from one layer to the other. As the mixed layer grows during the morning hours, it entrains air from the CCL. The reverse process takes place in the afternoon as the mixed layer decays. Turbulent transport through the inversion provides an additional means of mass exchange. We represent this turbulent transport using an exchange velocity, $V$ (in centimeters per second), which defines the flux $F$ between the two layers as

$$
F=V\left(C_{2}-C_{1}\right)
$$

where $C_{1}$ and $C_{2}$ are the concentrations in each layer. Characteristic length scales for heat and moisture transport above the canopy are about $100 \mathrm{~m}$ in the daytime and $50 \mathrm{~m}$ at night [Fitzjarrald et al., this issue]. Eddy diffusion coefficients across the interface between the mixed layer and the CCL are estimated to be of order $1 \times 10^{5} \mathrm{~cm}^{2} \mathrm{~s}^{-1}$ in the daytime and $2 \times 10^{3} \mathrm{~cm}^{2} \mathrm{~s}^{-1}$ at night [cf. Kaplan et al., this issue; Kirchhoff et al., submitted manuscript, 1987]. Therefore we assume turbulent exchange velocities between the two layers of $10 \mathrm{~cm}$ $\mathrm{s}^{-1}$ and $0.4 \mathrm{~cm} \mathrm{~s}^{-1}$ for day and night, respectively.

Measured or estimated emission and deposition rates provide flux boundary conditions at the bottom of the mixed layer. The canopy is regarded as a source of nitrogen oxides and isoprene to the mixed layer. Nitrogen oxides are emitted from soils and are transported vertically through the canopy to the atmosphere above [Kaplan et al., this issue]. We assume an emission flux for $\mathrm{NO}_{x}$ of $5.2 \times 10^{10}$ molecules $\mathrm{cm}^{-2} \mathrm{~s}^{-1}$, which is the median value measured during ABLE $2 \mathrm{~A}$ by Kaplan et al. [this issue]. Isoprene emission from vegetation is strongly sensitive to temperature and radiation and will be modeled as discussed in section 4. Primary emissions of nonmethane hydrocarbons other than isoprene are ignored, since these hydrocarbons are present at concentrations much lower than isoprene and have little influence on photochemistry [Zimmerman et al., this issue].

Deposition of trace gases to the forest appears to proceed rapidly for many species. During ABLE $2 \mathrm{~A}$, Kaplan et al. [this issue ] measured an average deposition velocity of $2 \mathrm{~cm} \mathrm{~s}^{-1}$ for $\mathrm{O}_{3}$. This high value may be explained by the large surface area associated with the vegetation canopy. The vertical gradient of $\mathrm{O}_{3}$ was found by Kaplan et al. [this issue] to be confined mostly to the lower $10 \mathrm{~m}$ above the ground, indicating little aerodynamic resistance to downward transport above the canopy. On the basis of this result we assume deposition velocities at the bottom of the mixed layer of $3 \mathrm{~cm} \mathrm{~s}^{-1}$ for $\mathrm{HNO}_{3} ; 2 \mathrm{~cm} \mathrm{~s}^{-1}$ for $\mathrm{O}_{3}$, isoprene, $\mathrm{NO}_{2}$, and PAN-type species; $1 \mathrm{~cm} \mathrm{~s}^{-1}$ for aldehydes, peroxides, and organic acids; and $0.5 \mathrm{~cm} \mathrm{~s}^{-1}$ for NO. It is assumed that other species are not removed by deposition.

Transport through the top of the CCL appears to be slow. For example, Kousky and Kagano [1981] report very small mean subsidence velocities, in the range $0-0.5 \mathrm{~cm} \mathrm{~s}^{-1}$, at 2000 $\mathrm{m}$ during the dry season. Some convective mass exchange must occur occasionally, but the rate is difficult to evaluate. We assume, somewhat arbitrarily, a mass exchange velocity of $0.2 \mathrm{~cm} \mathrm{~s}^{-1}$ as a boundary condition at the top of the CCL. The layer above $2000 \mathrm{~m}$ is assumed to contain $70 \mathrm{ppb} \mathrm{CO}, 40$ ppb $\mathrm{O}_{3}, 130$ ppt PAN, 15 ppt NO, and 45 ppt $\mathrm{NO}_{2}$ [Gregory et al., this issue; Sachse et al., this issue; Torres and Buchan, this issue; Wofsy et al., this issue; Crutzen et al., 1985]. Concentrations of other trace species are assumed to be negligibly small. The predicted concentrations in the mixed layer and in the CCL show little sensitivity to the choice of these boundary conditions, because the fluxes through the 2000-m level are usually much smaller than exchanges between the canopy, the mixed layer, and the CCL.

A typical model run represented 5 successive days. The PBL composition was initialized at noon preceding the first day, using the assumed concentrations for the air above $2000 \mathrm{~m}$. After 5 days of simulation most of the species in the PBL were near steady state, i.e., their concentrations changed little between the fourth and the fifth day. Exceptions included $\mathrm{CO}$ and formic acid, as discussed later; concentrations of these species were still increasing on the fifth model day. The results presented in this paper are taken from day 5 of the simulation.

\section{ISOPRENE}

Isoprene emissions from vegetation are strongly dependent on temperature and radiation. We assume an exponential dependence on temperature with a coefficient of 0.2 per degree Kelvin, on the basis of data reported by Lamb et al. [1985]. Nighttime emission is negligible. In the daytime we model the forest canopy as a gray absorbing layer with optical depth $\tau=3$ [Geiger, 1956]. We assume that isoprene emission throughout the canopy responds to light, in the manner reported by Tingey et al. [1979]. The daytime isoprene emission flux $E$ (in molecules per square centimeter per second) is then given by

$$
\begin{aligned}
E=8 \times 10^{7} \exp [0.2(T-298)] \\
\qquad \int_{0}^{\tau} \exp \left(\frac{10.2}{1+\exp \{-0.0064[I(s)-11.0]\}}\right) d s
\end{aligned}
$$

with

$$
I(s)=I_{0} \exp \frac{-s}{\cos \alpha}
$$

where $T$ is the temperature (in degrees Kelvin), assumed uniform throughout the canopy, $\alpha$ is the sun angle, $I_{0}$ is the photosynthetically active irradiance (in micromoles photons $\mathrm{m}^{-2} \mathrm{~s}^{-1}$ ) at the top of the canopy, and $s$ is an integration variable, which ranges from 0 to $\tau$. We use the mean diurnal cycle of incident radiation measured at the top of the canopy during ABLE 2A [Fitzjarrald et al., this issue] and assume that $50 \%$ of this incident radiation is photosynthetically active [Strickland, 1958]. The multiplicative constant $\left(8 \times 10^{7}\right)$ is the only adjustable parameter in our expression of the isoprene emission flux and is selected to match the midday concentrations of isoprene observed by Zimmerman et al. [this issue] during $A B L E$ 2A.

The diurnal range of air temperatures over the Amazon forest is small (Figure 3), so that radiation is the main factor responsible for variation in isoprene emission during the day. Equation (2) indicates that isoprene emission becomes light saturated at irradiances above $400 \mu$ moles photons $\mathrm{m}^{-2} \mathrm{~s}^{-1}$. At the top of the canopy, such a value is attained 1 hour after sunrise. However, the irradiance is much lower within the canopy, as a result of absorption and scattering of light by vegetation. Therefore the dependence of isoprene emission on incident radiation remains strong within the canopy throughout the day, so that model emission rates maximize at noon (Figure 4). The isoprene emission rate averaged over the daytime hours is $7.7 \times 10^{11}$ molecules $\mathrm{cm}^{-2} \mathrm{~s}^{-1}$, or $38 \mathrm{mg}$ isoprene $\mathrm{m}^{-2} \mathrm{~d}^{-1}$. This value is in the range of emission rates 


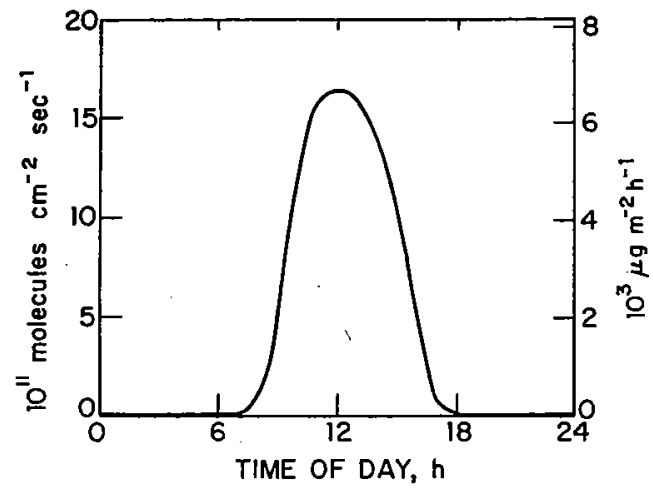

Fig. 4. Calculated isoprene emission flux from the Amazon forest as a function of time of day.

reported by Lamb et al. [1985] for deciduous forests in North America.

A strong dependence of isoprene emission on sun angle, as simulated earlier, is necessary to explain the observation that isoprene concentrations in the mixed layer peak at midday [Zimmerman et al., this issue]. If isoprene were emitted at a constant rate during the daylight hours, concentrations in the mixed layer would instead peak in the early morning and in the late afternoon, when vertical dilution is minimum and the chemical sink is slow [Jacob and Wofsy, 1988].

Isoprene was found to be depleted from the mixed layer within a few hours following sunset but was not depleted aloft. Nighttime vertical profiles of isoprene measured during ABLE $2 \mathrm{~A}$ indicate a rapid sink of isoprene within the canopy [ $\mathrm{Zim}$ merman et al., this issue; Rasmussen and Khalil, this issue]. We represented the apparent nighttime isoprene sink by a deposition velocity $\left(2 \mathrm{~cm} \mathrm{~s}^{-1}\right)$ at the bottom of the mixed layer (top of the canopy). Zimmerman et al. [this issue] have suggested that reaction with $\mathrm{NO}_{3}$ may provide the main nighttime sink of isoprene in the canopy. They argue that NO emisssions from soils are sufficiently rapid to quantitatively deplete isoprene, even if only a small fraction of the emitted $\mathrm{NO}$ is converted to $\mathrm{NO}_{3}$. However, the rate-limiting step for $\mathrm{NO}_{3}$ production is not emission of $\mathrm{NO}$, but reaction of $\mathrm{NO}_{2}$ with $\mathrm{O}_{3}$, which is slow. From the data of Kaplan et al. [this issue] we estimate upper limits for the concentrations of $\mathrm{NO}_{2}$ and $\mathrm{O}_{3}$ within the canopy of 1 and $20 \mathrm{ppb}$, respectively. The maximum $\mathrm{NO}_{3}$ production rate calculated from these upper limits is 55 ppt per hour, which is much too slow to result in significant isoprene depletion over the course of the night. Therefore we argue that reaction with $\mathrm{NO}_{3}$ cannot be the primary mechanism for isoprene removal at night. Some other mechanism, such as deposition to vegetation, must be involved.

The calculated diurnal cycles of isoprene in the mixed layer and in the CCL are shown in Figure 5. The median concentrations measured by Zimmerman et al. [this issue] in the mixed layer are superimposed on the simulated values. The model reproduces observations very well, but this is expected, since model parameters have been adjusted to obtain this result. The unusually high $1500 \mathrm{LT}$ measurements, which are not reproduced by the model, were reported for an isolated day where meteorological conditions may have departed significantly from those assumed in our calculations.

The daytime mixed layer concentrations of $2.5-3 \mathrm{ppb}$ are controlled by a balance between emission from vegetation and reaction with $\mathrm{OH}$, the main daytime sink. The atmospheric lifetime of isoprene at noon is about 3 hours. Levels of isoprene are sufficiently high that the concentration of $\mathrm{OH}$ is, in

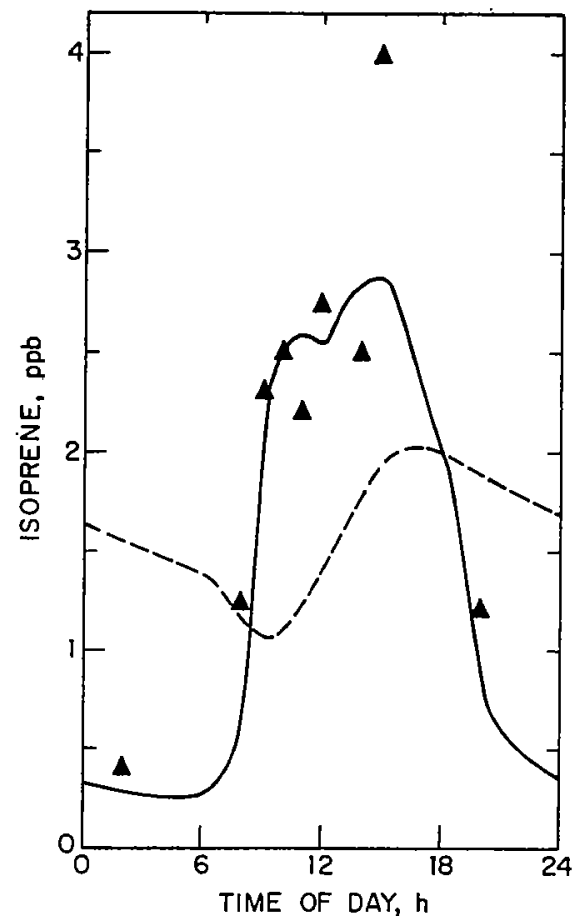

Fig. 5. Isoprene concentrations as a function of time of day in the mixed layer (solid line) and in the CCL (dashed line). The triangles are the median mixed layer concentrations measured by Zimmerman et al. [this issue] during ABLE $2 \mathrm{~A}$

turn, controlled by isoprene; the main sinks for $\mathrm{OH}$ are reactions with isoprene and its decomposition products (methylvinylketone, methacrolein, formaldehyde). As a result, the computed isoprene concentration responds in a strongly nonlinear manner to changes in the assumed source. In Figure 6 we show the predicted noontime concentrations of isoprene and $\mathrm{OH}$ as a function of the isoprene source strength. The concentration of $\mathrm{OH}$ decreases as the isoprene source increases, and consequently, the isoprene concentration rises almost as the square of the source strength. Therefore the isoprene data collected during ABLE $2 \mathrm{~A}$ provide a relatively. strong constraint on the assumed rate for isoprene emission.

Most of the isoprene emitted over the course of the day is converted to oxygenated hydrocarbons within the PBL. Photooxidation of isoprene in the model produces $17 \mathrm{ppb}$ of nonmethane hydrocarbons in the daytime mixed layer (Table 1). The main species produced are organic peroxides, formaldehyde, methylvinylketone, and methacrolein. These species may be oxidized further within the PBL to eventually produce CO. Alternatively, they may be removed by deposition or by transport to the free troposphere. In our simulation the accumulation of $\mathrm{CO}$ in the $\mathrm{PBL}$ due to the isoprene source amounts to $4 \mathrm{ppb} \mathrm{d}^{-1}$; CO levels increase from 70 to $89 \mathrm{ppb}$ over 5 days of undisturbed conditions. A $\mathrm{CO}$ enrichment of this magnitude is typical of those observed during ABLE $2 \mathrm{~A}$ (Figure 1; see also Sachse et al. [this issue]. Evidently, isoprene photooxidation could be significant in producing the $\mathrm{CO}$ enrichments observed in the PBL under nonpolluted conditions.

\section{OdD NitrogeN}

The concentrations of odd nitrogen species in each layer are shown in Figure 7 as a function of time of day. We define $\mathrm{NO}_{x}$ as $\left(\mathrm{NO}+\mathrm{NO}_{2}\right), \mathrm{NO}_{t}$ as $\left(\mathrm{NO}_{x}+\mathrm{HNO}_{2}+\mathrm{HNO}_{3}\right)$, and $\mathrm{NO}_{y}$ 


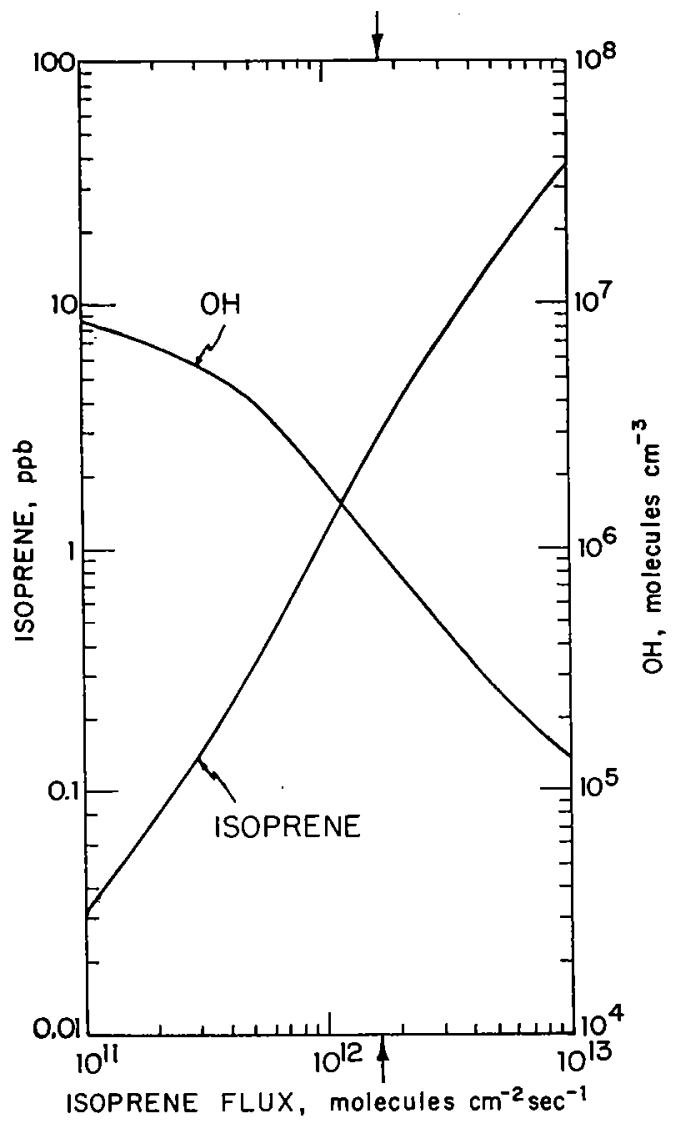

Fig. 6. Isoprene and $\mathrm{OH}$ concentrations at noon in the mixed layer, as a function of the noontime isoprene emission flux. The isoprene fluxes were calculated from equation (2) with a range of values for the multiplicative constant $\left(8 \times 10^{7}\right.$ in the standard simulation) The arrow on the abscissa scale indicates the emission flux used in the standard model simulation.

as $\left(\mathrm{NO}_{2}+\mathrm{PANS}+\right.$ organic nitrates). The other odd nitrogen species, $\mathrm{NO}_{3}, \mathrm{~N}_{2} \mathrm{O}_{5}$, and $\mathrm{HNO}_{4}$, do not contribute significantly to the odd nitrogen pool. The notation "PANs" represents the sum of the species PAN, PPN, MPAN, and IPAN (Table 2). The organic nitrates are low-yield addition products of the $\mathrm{RO}_{2}+\mathrm{NO}$ reactions [Atkinson and Lloyd, 1984].

The main source of $\mathrm{NO}_{y}$ is emission of NO from soils, and the main sink is deposition as $\mathrm{NO}_{2}$ and PANs. Exchange with air aloft has only a small effect on the $\mathrm{NO}_{y}$ budget in the model. Nighttime $\mathrm{NO}_{y}$ concentrations in the mixed layer are relatively high because vertical dilution of emissions is minimum. Values are relatively constant through the night, reflecting a balance between emission of $\mathrm{NO}$ and deposition of $\mathrm{NO}_{2}$. At sunrise a transient increase in $\mathrm{NO}_{y}$ is predicted. This increase is due to photolysis of $\mathrm{NO}_{2}$ to $\mathrm{NO}$, resulting in a decrease of the rate for deposition. The $\mathrm{NO}_{y}$ concentration in the mixed layer declines during the morning hours as low-NO $\mathrm{NO}_{y}$ air from the CCL is progressively entrained into the mixed layer. By $1100 \mathrm{LT}$, the gradient between the mixed layer and the CCL has vanished. Deposition is a relatively inefficient sink in the daytime because the mixed layer is deep. As a result, $\mathrm{NO}_{y}$ concentrations in both layers increase during the afternoon hours.

Concentrations measured during ABLE 2A under unpolluted conditions are generally consistent with our model results. Daytime concentrations of NO reported by Torres and Buchan [this issue] ranged from 20 to $35 \mathrm{ppt}$ in the mixed layer, except between 0800 and 0900 LT, when concentrations were higher (up to $65 \mathrm{ppt}$ ). Concentrations in the CCL ranged from 10 to $20 \mathrm{ppt}$. Model predictions are in excellent agreement with these data (Figure 7). Andreae et al. [this issue (b)] reported a mean boundary layer concentration of $171 \mathrm{ppt}$ for total inorganic nitrate, $\left(\mathrm{HNO}_{3}(\mathrm{~g})+\mathrm{NO}_{3}{ }^{-}\right)$. They found that most of the inorganic nitrate was present as aerosol $\mathrm{NO}_{3}{ }^{-}$. The model, which does not take into account formation of aerosol $\mathrm{NO}_{3}{ }^{-}$, predicts $\mathrm{HNO}_{3}(\mathrm{~g})$ concentrations of about 70 ppt. The main sink for $\mathrm{HNO}_{3}(\mathrm{~g})$ is deposition and, since the deposition velocity of aerosol $\mathrm{NO}_{3}{ }^{-}$is expected to be lower than that of $\mathrm{HNO}_{3}(\mathrm{~g}), 70 \mathrm{ppt}$ would constitute a lower limit for inorganic nitrate as predicted by the model. Good agreement with data can be achieved by assuming that conversion of $\mathrm{HNO}_{3}(\mathrm{~g})$ to $\mathrm{NO}_{3}{ }^{-}$aerosol leads to a decrease by a factor of 4 in the deposition velocity of inorganic nitrate, which seems reasonable.

Most of the $\mathrm{NO}_{y}$ in the model is present in the form of PANs. We predict concentrations of PANs as high as $0.5 \mathrm{ppb}$ at midday in the CCL, with slightly lower values in the mixed layer (Figure 7c). Peroxyacetyl nitrate is the dominant PAN species, but higher PANs also make substantial contributions, in particular MPAN produced from the reaction of methacrolein with $\mathrm{OH}$ (Table 2). Because the PANs are produced phtochemically, their concentrations are highest during the day. At night, very low levels are predicted in the mixed layer because of deposition. However, concentrations aloft remain fairly high $(0.4 \mathrm{ppb})$ through the night.

\section{OZONE}

We show the predicted diurnal cycles of ozone in the mixed layer and in the CCL in Figure 8. Data from a number of vertical profiles [Gregory et al., this issue], averaged over each layer, are superimposed on the model predictions. Profiles affected by biomass burning, as diagnosed by $\mathrm{CO}$ levels higher than $100 \mathrm{ppb}$ [Andreae et al., this issue (b)] are excluded. Model and observations are seen to be in good agreement.

A diurnal cycle of large amplitude is predicted in the mixed layer, consistent with the data of Gregory et al. [this issue] and Kirchhoff et al. (submitted manuscript, 1987). The $\mathrm{O}_{3}$ concentration drops to less than $5 \mathrm{ppb}$ at night because of rapid deposition to the forest. In the morning the onset of photochemical activity leads to a rapid increase in con-

TABLE 1. Predicted Concentrations of Nonmethane Hydrocarbons Produced From Isoprene

\begin{tabular}{lc}
\multicolumn{1}{c}{ Species } & $\begin{array}{c}\text { Concentration, } \\
\mathrm{ppb}\end{array}$ \\
\hline Organic peroxides & 4.3 \\
Formaldehyde & 3.2 \\
Isoprene & 2.5 \\
Methylvinylketone & 2.5 \\
Methacrolein & 2.0 \\
Organic acids & 0.6 \\
C -aldehydes & 0.5 \\
Hydroxyacetaldehyde & 0.4 \\
PANs & 0.4 \\
Acetaldehyde & 0.3 \\
Methylglyoxal & 0.1 \\
Alkyl nitrates & 0.1 \\
Methanol & 0.1 \\
Total & 17.0 \\
\hline
\end{tabular}

Values are for mixed layer at noon. 

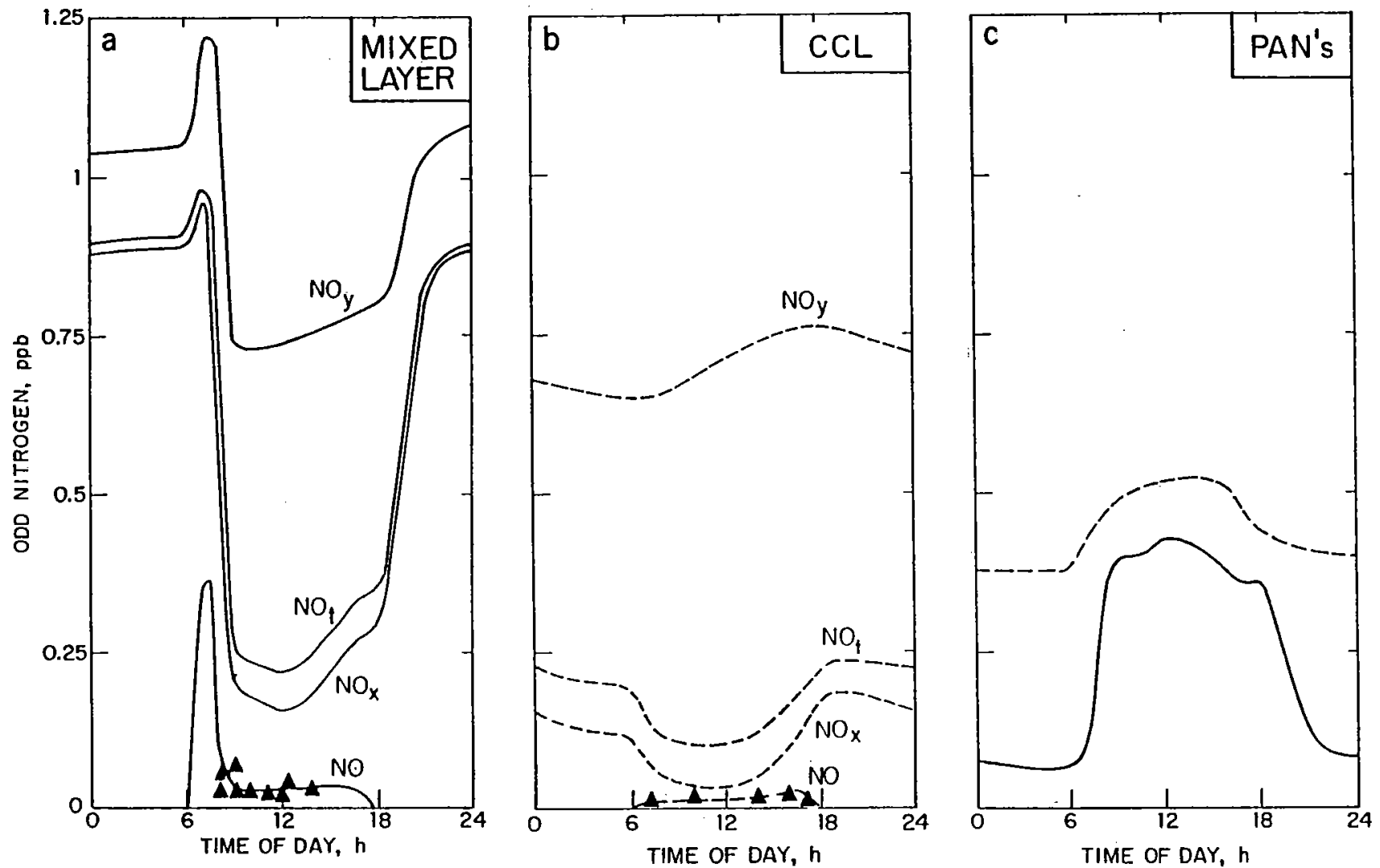

Fig. 7. Odd nitrogen concentrations as a function of time of day: (a) mixed layer; $(b)$ CCL; $(c)$ PANs in the mixed layer (solid line) and in the CCL (dashed line). $\mathrm{NO}_{x}$ denotes $\left(\mathrm{NO}+\mathrm{NO}_{2}\right), \mathrm{NO}_{t}$ denotes $\left(\mathrm{NO}_{x}+\mathrm{HNO}_{2}+\mathrm{HNO}_{3}\right)$, and $\mathrm{NO}_{y}$ denotes $\left(\mathrm{NO}_{t}+\right.$ PANs + organic nitrates). The triangles are the median NO concentrations measured by $T$ Torres and Buchan [this issue] during ABLE $2 \mathrm{~A}$

centration. A broad maximum of $20 \mathrm{ppb}$ is predicted between 1200 and 1700 LT. By contrast, little diurnal variation is predicted in the CCL. The concentration peaks at $22 \mathrm{ppb}$ in the midafternoon, but remains near $20 \mathrm{ppb}$ at night. Vertical profiles of $\mathrm{O}_{3}$ concentrations are strongly inverted at night and in the morning because of the diurnal cycle in the mixed layer. The profiles are still inverted in the afternoon, but the gradients are considerably weaker.

Ozone concentrations in the model are controlled primarily by photochemical production and by deposition to the forest. Downward transport of $\mathrm{O}_{3}$ from the free troposphere is slow compared to the photochemical source. To evaluate the effect of the source from the free troposphere in the model, we con-

TABLE 2. Predicted Concentrations of PANs and Organic Nitrates Produced From Isoprene

\begin{tabular}{llc}
\hline Species & \multicolumn{1}{c}{ Formula } & $\begin{array}{c}\text { Concentration, } \\
\text { ppb }\end{array}$ \\
\hline PANs & & \\
PAN & $\mathrm{CH}_{3} \mathrm{C}(\mathrm{O}) \mathrm{OONO}_{2}$ & 0.27 \\
MPAN & $\mathrm{CH}_{2} \mathrm{C}\left(\mathrm{CH}_{3}\right) \mathrm{C}_{2}(\mathrm{O}) \mathrm{ONO}_{2}$ & 0.09 \\
PPN & $\mathrm{CH}_{3} \mathrm{CH}_{2} \mathrm{C}(\mathrm{O}) \mathrm{ONO}_{2}$ & 0.04 \\
IPAN & $\mathrm{HOCH}_{2} \mathrm{C}(\mathrm{O}) \mathrm{ONO}_{2}$ & 0.03 \\
Organic & $\mathrm{CH}_{2} \mathrm{C}\left(\mathrm{CH}_{3}\right) \mathrm{CH}(\mathrm{OH}) \mathrm{CH}_{2} \mathrm{ONO}_{2}$ & 0.06 \\
nitrates & $($ and isomers) & \\
$\mathrm{C}_{4}$ alkyl & & 0.02 \\
nitrates & & \\
Total & & 0.51 \\
\hline
\end{tabular}

Values are for mixed layer at noon. ducted a simulation in which no exchange across the top of the CCL was allowed. This simulation predicted noontime $\mathrm{O}_{3}$ concentrations of 18.5 and $18.3 \mathrm{ppb}$ in the mixed layer and in the CCL, respectively, as compared to 19.9 and $20.2 \mathrm{ppb}$ from the standard simulation (Figure 8). Although the difference between these results is small, the downward flux of $\mathrm{O}_{3}$ from the free troposphere helps to maintain a slight inverted gradi-

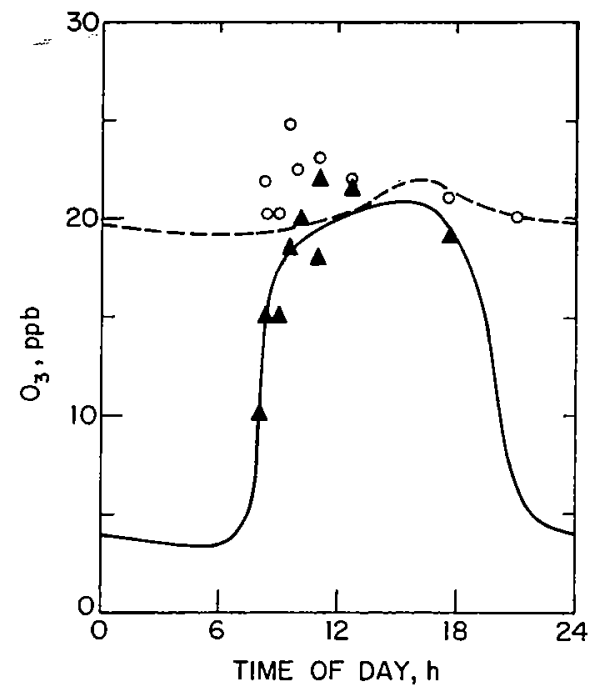

Fig. 8. Ozone concentrations as a function of time of day in the mixed layer (solid line) and in the CCL (dashed line). The solid triangles and the open circles are observed concentrations in the mixed layer and in the CCL, respectively [Gregory et al., this issue], averaged as described in the text. 


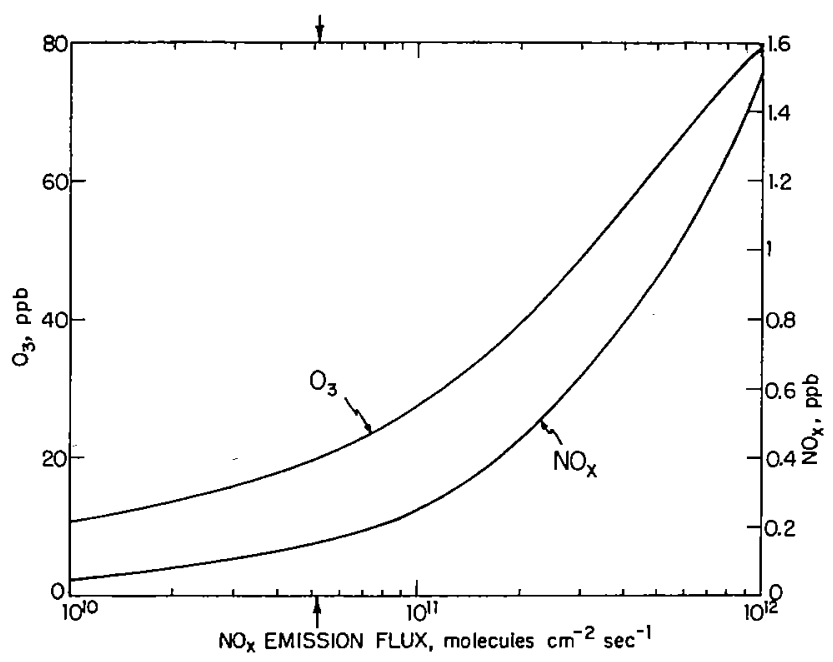

Fig. 9. Ozone and $\mathrm{NO}_{x}$ concentrations at noon in the mixed layer as a function of the NO emission flux. The arrow on the abscissa scale indicates the emission flux used in the standard model simulation.

ent in the $\mathrm{O}_{3}$ vertical profile throughout the day, as observed by Gregory et al. [this issue].

Downward transport of $\mathrm{O}_{3}$ from the free troposphere could possibly affect $\mathrm{PBL}$ concentrations to a larger extent than is simulated by the model, because the rates of mass transport across the trade wind inversion are uncertain. Nevertheless, local photochemical production of $\mathrm{O}_{3}$ must proceed rapidly over the forest, considering that NO concentrations measured in the mixed layer ranged from 20 to 65 ppt [Torres and Buchan, this issue]. Lidar measurements [Browell et al., this issue] provide strong evidence of a biogenic source for $\mathrm{O}_{3}$. Isolated regions of high $\mathrm{O}_{3}$ concentrations ( $30-40 \mathrm{ppb}$ ) were observed above the forest canopy which were not associated with biomass burning or urban pollution (as would be indicated by elevated (CO). Browell et al. [this issue] found that $\mathrm{O}_{3}$ levels in the PBL fluctuated substantially over spatial scales of a few kilometers and attributed this behavior to inhomogeneities in the upward flux of $\mathrm{NO}_{x}$ from the canopy to the mixed layer. Indeed, the data of Torres and Buchan [this issue] indicate large fluctuations of NO concentrations above the canopy.

Photochemical production of $\mathrm{O}_{3}$ in the PBL is controlled by the availability of $\mathrm{NO}_{x}$. Midday levels of $\mathrm{NO}$ in the mixed layer are only about $30 \mathrm{ppt}$, as compared to $17 \mathrm{ppb}$ of nonmethane hydrocarbons. Figure 9 shows the response of the noontime mixed layer $\mathrm{O}_{3}$ concentration to changes in emission of $\mathrm{NO}_{x}$. The computed $\mathrm{O}_{3}$ concentration is strongly dependent on the strength of the $\mathrm{NO}_{x}$ source for the range of NO emissions reported by Kaplan et al. [this issue]. As the NO source decreases below the value reported by Kaplan et al. [this issue] photochemical production of $\mathrm{O}_{3}$ slows down, and $\mathrm{O}_{3}$ levels become increasingly controlled by downward transport from the free troposphere.

By contrast, the strength of the isoprene source has little effect on $\mathrm{O}_{3}$ production (Figure 10). In the absence of isoprene, oxidation of $\mathrm{CO}$ would be sufficient to drive the odd hydrogen cycle and to supply noontime $\mathrm{O}_{3}$ concentrations of about $20 \mathrm{ppb}$. Very large isoprene sources would deplete $\mathrm{O}_{3}$, because of direct reactions of $\mathrm{O}_{3}$ with isoprene and methylvinylketone. However, such strong sources would imply isoprene concentrations considerably in excess of those measured in ABLE 2A (see Figure 6).
Model $\mathrm{O}_{3}$ concentrations in the $\mathrm{CCL}$ peak at a slightly later time of day than in the mixed layer. This result reflects the distribution of $\mathrm{NO}_{x}$ in the model. High concentrations of $\mathrm{NO}_{x}$ in the morning mixed layer (Figure 7) lead to rapid production of $\mathrm{O}_{3}$ beginning shortly after sunrise. By contrast, there is little $\mathrm{O}_{3}$ production in the CCL, where the $\mathrm{NO}_{x}$ levels are much lower. Ozone production is more significant in the CCL during the afternoon hours due to upward transport of $\mathrm{NO}_{x}$ from the mixed layer.

We have shown in the previous section that most of the $\mathrm{NO}_{y}$ in the PBL is present in the form of PANs. Evidently, conversion of $\mathrm{NO}_{x}$ to PANs plays a critical role in moderating the boundary layer photochemistry: if PANs were not formed, considerably more ozone would be produced. One might expect that an increase in the isoprene source would lead to a reduction in ozone production by enhancing the fraction of odd nitrogen stored as PANs. Such an effect is not predicted by the model, however, because of the feedback between isoprene and $\mathrm{OH}$ (Figure 6). We find that the predicted concentrations of PANs are insensitive to the strength of the isoprene source once that source is large enough to control the $\mathrm{OH}$ concentration (about half of the isoprene flux assumed in our simulation).

\section{ORGaNIC ACIDS}

The model predicts that photochemical decomposition of isoprene in the gas phase produces substantial concentrations of formic acid, methacrylic acid, and pyruvic acid (Figure 11). Starting from an initially low concentration, $\mathrm{HCOOH}$ accumulates to $0.5 \mathrm{ppb}$ after 5 model days, and its concentration is still increasing. During the fifth model day, $\mathrm{HCOOH}$ is produced in the PBL at a rate of $0.28 \mathrm{ppb} \mathrm{d}^{-1}$, primarily from the reactions of isoprene and methylvinylketone with $\mathrm{O}_{3}$. It is removed by deposition $\left(0.15 \mathrm{ppb} \mathrm{d}^{-1}\right)$ and by ventilation through the top of the CCL $\left(0.05 \mathrm{ppb} \mathrm{d}^{-1}\right)$. The balance $(0.08$ ppb $\mathrm{d}^{-1}$ ) accumulates in the PBL. The HCOOH concentration in the mixed layer drops to a low value at night, as a result of rapid deposition. The concentration aloft does not vary significantly with time of day.

The deposition and ventilation sinks, as formulated in the model, result in a lifetime for $\mathrm{HCOOH}$ of 2.5 days in the PBL. A steady state $\mathrm{HCOOH}$ concentration of $0.7 \mathrm{ppb}$ would thus be reached after about 8 model days. It must be pointed out that the predicted $\mathrm{HCOOH}$ levels scale as the inverse of the

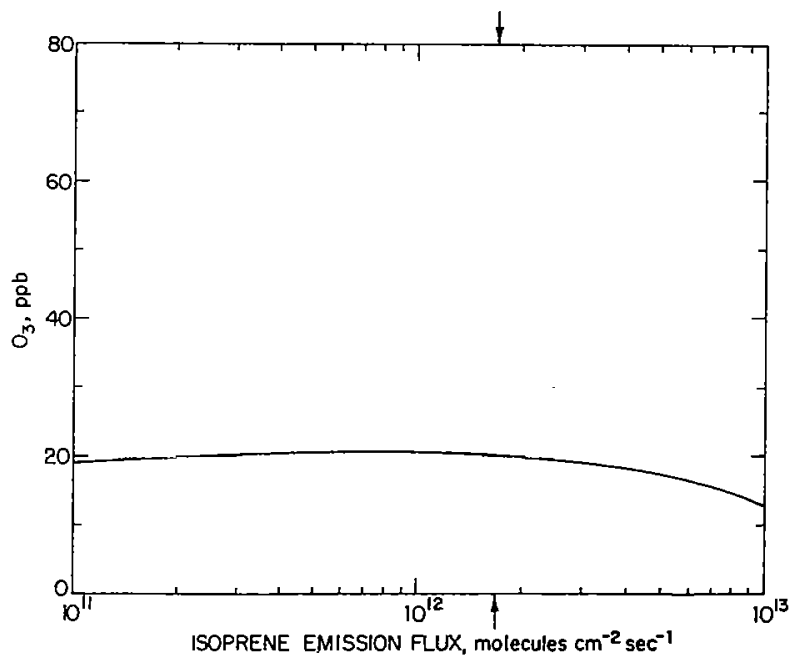

Fig. 10. Ozone concentrations at noon in the mixed layer as a function of the isoprene emission flux. The arrow on the abscissa scale indicates the emission flux used in the standard simulation. 

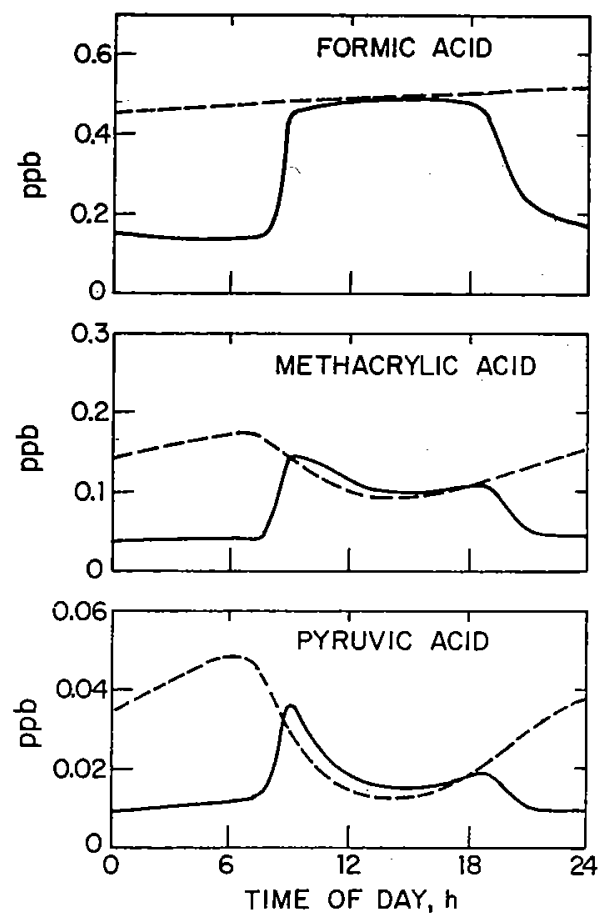

Fig. 11. Concentrations of formic acid, methacrylic acid, and pyruvic acid as a function of time of day in the mixed layer (solid line) and in the CCL (dashed line). Day 5 of the simulation is shown; note the secular increase of $\mathrm{HCOOH}$.

rates assumed for deposition and ventilation. These rates are probably uncertain by about a factor of 2 , and similar uncertainty would apply to the predicted concentrations of $\mathrm{HCOOH}$.

Clouds in the CCL can play a major role in the $\mathrm{HCOOH}$ budget. Formic acid is produced rapidly in cloud droplets by aqueous-phase oxidation of formaldehyde [Chameides, 1984]. The mean PBL formaldehyde concentration calculated from the isoprene source is $3.2 \mathrm{ppb}$ (Table 1), so that substantial production of $\mathrm{HCOOH}$ could take place by processing of air through the CCL. However, $\mathrm{HCOOH}$ is also rapidly destroyed in cloud droplets by aqueous-phase oxidation of $\mathrm{HCOO}^{-}$, and this sink may balance the aqueous-phase source [Jacob, 1986]. We simulated in a previous study the coupled gas-phase/aqueous-phase chemistry occurring within clouds over the Amazon forest, and concluded that total $\mathrm{HCOOH}$ $\left(\mathrm{HCOOH}(\mathrm{g})+\mathrm{HCOOH}(\mathrm{aq})+\mathrm{HCOO}^{-}\right)$concentrations in the clouds could be at most $1 \mathrm{ppb}$ [Jacob and Wofsy, 1988].

The above analysis suggests that the isoprene source could account for $\mathrm{HCOOH}$ concentrations in the range $0.5-1 \mathrm{ppb}$ over the Amazon forest. These can be compared to the values measured by Andreae et al. [this issue (a)] within the forest canopy during ABLE 2A. The $\mathrm{HCOOH}$ concentrations measured by Andreae et al. were approximately constant during the daylight hours and dropped to low values at night, a resul' in harmony with model predictions. Observed daytime concentrations were in the range $1-3 \mathrm{ppb}$, somewhat higher than simulated values. This discrepancy suggests that other sources besides oxidation of isoprene could be important for $\mathrm{HCOOH}$. Oxidation of ethene or propene could not provide a significant source at the concentrations measured by Zimmerman et al. [this issue]. Primary emissions from vegetation, ants [Graedel, 1987], and soils may need to be considered. Since the measurements of Andreae et al. [this issue (a)] were made within the canopy, they would be particularly affected by a primary source.
According to our mechanism, photochemical decomposition of isoprene produces methacrylic acid and pyruvic acid in addition to $\mathrm{HCOOH}$. Both methacrylic acid and pyruvic acid have fairly rapid photochemical sinks, which would tend to control their concentrations. The formic:methacrylic:pyruvic concentration ratios predicted from the isoprene source are of order (25-50):5:1. We are not aware of any measurements of methacrylic acid in the atmosphere, but measurements of pyruvic acid were made by Andreae et al. [1987] during ABLE 2A. Pyruvic acid was present ubiquitously in gas-phase, aerosol, and precipitation samples. The formic-to-pyruvic ratios in precipitation ranged from 13 to 62 , with a mean value of 40 . Gas-phase concentrations of pyruvic acid within the canopy ranged from 80 to $400 \mathrm{ppt}$, with a mean value of $180 \mathrm{ppt}$. These results are consistent with an isoprene source for pyruvic acid as simulated by the model, though observed gas-phase concentrations are higher than predicted. Pyruvic acid is unlikely to be released from vegetation because of its high acidity constant ( $p K 2.4$ ), and appears to have no significant atmospheric sources other than the oxidation of isoprene. Grosjean [1984] has reported the photochemical production of pyruvic acid from o-cresol, but this source may be significant only in polluted urban atmospheres.

High levels of acetic acid have been observed in the Amazon forest. Andreae et al. [this issue (a)] reported daytime $\mathrm{CH}_{3} \mathrm{COOH}$ concentrations ranging from 1 to $5 \mathrm{ppb}$ within the canopy. Keene and Galloway [1986] reported a mean $\mathrm{CH}_{3} \mathrm{COO}^{-}$concentration of $3.7 \mu \mathrm{eq} \mathrm{L}^{-1}$ in precipitation over central Brazil. In our chemical mechanism, photooxidation of isoprene does not produce $\mathrm{CH}_{3} \mathrm{COOH}$. Furthermore, we have shown previously that production of $\mathrm{CH}_{3} \mathrm{COOH}$ by aqueousphase reactions in clouds is negligibly slow [ Jacob and Wofsy, 1988]. It appears that primary emissions from vegetation or soils may constitute the main source of atmospheric $\mathrm{CH}_{3} \mathrm{COOH}$ over the Amazon forest. Atmospheric oxidation of terpenes could also, perhaps, produce $\mathrm{CH}_{3} \mathrm{COOH}$. Keene and Galloway [1986] have argued that $\mathrm{HCOOH}$ and $\mathrm{CH}_{3} \mathrm{COOH}$ must be produced by a common source in order to explain the high correlation observed between $\mathrm{HCOO}^{-}$ and $\mathrm{CH}_{3} \mathrm{COO}^{-}$levels in precipitation. However, such a correlation could be rationalized also for a mechanism where $\mathrm{HCOOH}$ was a secondary product from isoprene oxidation, while $\mathrm{CH}_{3} \mathrm{COOH}$ was a primary product of the forest vegetation or a secondary product from oxidation of terpenes.

Acknowledgments. We thank the following colleagues for valuable comments on the manuscript: J. A. Logan and M. B. McElroy (Harvard University), R. B. Chatfield (NCAR), M. O. Andreae (Florida State University), V. W. J. H. Kirchhoff (INPE), and an anonymous reviewer. This research was supported by funds from the National Aeronautics and Space Administration (grant NASA NAGI-55), the National Science Foundation (grant NSF-ATM 8413153), and the Coordinating Research Council (grant CRC-CAPA-22-83).

\section{REFERENCES}

Andreae, M. O., R. W. Talbot, and S.-M. Li, Atmospheric measurements of pyruvic and formic acid, J. Geophys. Res., 92, 6635-664, 1987.

Andreac, M. O. R. W. Talbot, T. W. Andreae, and R. C. Harriss, Formic and acetic acid over the central Amazon region, Brazil, 1 Dry season, J. Geophys. Res., this issue (a).

Andreae, M. O., et al., Biomass-burning emissions and associated haze layers over Amazonia, J. Geophys. Res., this issue (b).

Atkinson, R., Kinetics and mechanisms of the gas-phase reactions of the hydroxyl radical with organic compounds under atmospheric conditions, Chem. Rev., 86, 69-201, 1986.

Atkinson, R., and A. L. Lloyd, Evaluation of kinetic and mechanistic 
data for modeling of photochemical smog, J. Phys. Chem. Ref. Data, 13, 315-444, 1984.

Browell, E. V., G. L. Gregory, R. C. Harriss, and V. W. J. H. Kirchhoff, Tropospheric ozone and aerosol distributions across the Amazon Basin, J. Geophys. Res., this issue.

Calvert, J. G., and J. N. Pitts, Jr., Photochemistry, John Wiley, New York, 1966.

Chameides, W. L., The photochemistry of a remote marine stratiform cloud, J. Geophys. Res., 89, 4739-4755, 1984.

Crutzen, P. J., A. C. Delany, J. Greenberg, P. Haagenson, L. Heidt, R. Lueb, W. Pollock, W. Seiler, A. Wartburg, and P. Zimmerman, Tropospheric chemical composition measurements in Brazil during the dry season, J. Atmos. Chem., 2, 233-256, 1985.

Delany, A. C., P. Haagensen, S. Walters, A. F. Wartburg, and P. J. Crutzen, Photochemically produced ozone in the emission from large-scale tropical vegetation fires, J. Geophys. Res., 90, 2425-2429, 1985

Fitzjarrald, D. R., B. L. Stormwind, G. Fisch, and O. M. R. Cabral, Turbulent transport observed just above the Amazon forest, $J$. Geophys. Res., this issue.

Galbally, I. E., Emission of fixed nitrogen compounds to the atmosphere in remote areas, in Biogeochemical Cycles of Sulfur and $\mathrm{Ni}$ trogen in Remote Areas, edited by J. N. Galloway, R. J. Charlson, M. O. Andreae, and H. Rodhe, D. Reidel, Hingham, Mass., 1985.

Geiger, R., The Climate Near the Ground, p. 317, Harvard University Press, Cambridge, Mass., 1957.

Graedel, T. E., Atmospheric formic acid from formicine ants, Eos Trans. $A G U, 68,273,1987$.

Gregory, G. L., E. V. Browell, and L. S. Warren, Boundary layer ozone: An airborne survey above the Amazon Basin, J. Geophys. Res., this issue.

Grosjean, D., Atmospheric reactions of pyruvic acid, Atmos. Environ., $17,2379-2382,1983$.

Grosjean, D., Atmospheric reactions of ortho cresol: Gas phase and aerosol products, Atmos. Environ., 18, 1641-1652, 1984.

Harriss, R. C., et al., The Amazon Boundary Layer Experiment (ABLE 2A): Dry season 1985, J. Geophys. Res., this issue.

Hatakeyama, S., H. Bandow, M. Okuda, and H. Akimoto, Reactions of $\cdot \mathrm{CH}_{2} \mathrm{OO} \cdot$ and $\mathrm{CH}_{2}\left({ }^{1} \mathrm{~A}_{1}\right)$ with $\mathrm{H}_{2} \mathrm{O}$ in the gas phase, J. Phys. Chem., 85, 2249-2254, 1981.

Jacob, D. J., The chemistry of $\mathrm{OH}$ in remote clouds and its role in the production of formic acid and peroxymonosulfate, J. Geophys. Res., 91, 9807-9826, 1986

Jacob, D. J., and S. C. Wofsy, Photochemical production of carboxylic acids in a remote continental atmosphere, in Acid Deposition Processes at High Elevation Sites, edited by M. H. Unsworth, D. Reidel, Hingham, Mass., in press, 1988.

Kaplan, W. A., S. C. Wofsy, M. Keller, and J. M. daCosta, Emission of $\mathrm{NO}$ and deposition of $\mathrm{O}_{3}$ in a tropical forest system, J. Geophys. Res., this issue.

Keene, W. C., and J. N. Galloway, Considerations regarding sources for formic and acetic acids in the troposphere, J. Geophys. Res., 91, $14,466-14,474,1986$

Kousky, V. E., and M. T. Kagano, A climatological study of the tropospheric circulation over the Amazon region, Acta Amazonica, $11,743-758,1981$.

Lamb, B., H. Westberg, G. Allwine, and T. Quarles, Biogenic hydrocarbon emissions from deciduous and coniferous trees in the United States, J. Geophys. Res., 90, 2380-2390, 1985.
Lloyd, A. C., R. Atkinson, F. W. Lurmann, and B. Nitta, Modeling potential ozone impacts from natural hydrocarbons, I, Development and testing of a chemical mechanism for the $\mathrm{NO}_{x}$-air photooxidations of isoprene and $\alpha$-pinene under ambient conditions, Atmos. Environ., 17, 1931-1950, 1983.

Logan, J. A., M. J. Prather, S. C. Wofsy, and M. B. McElroy, Tropospheric chemistry: A global perspective, J. Geophys. Res., 86, 7210$7254,1981$.

Lurmann, F. W., A. C. Lloyd, and B. Nitta, Modeling potential ozone impacts from natural hydrocarbons, II, Hypothetical biogenic HC emission scenario modeling, Atmos. Environ., 17, 10,905-10,936, 1983.

Lurmann, F. W., A. C. Lloyd, and R. Atkinson, A chemical mechanism for use in long-range transport/acid deposition computer modeling, J. Geophys. Res., 91, 1905-1936, 1986.

Martin, C. L., D. Fitzjarrald, M. Garstang, A. P. Oliveira, S. Greco, and E. Browell, Structure and growth of the mixing layer over the Amazonian rain forest, J. Geophys. Res., this issue.

Rasmussen, R. A., and M. A. K. Khalil, Isoprene over the Amazon Basin, J. Geophys. Res., this issue.

Rosenfeld, R. N., and B. R. Weiner, Photofragmentation of acrylic acid and methacrylic acid in the gas phase, J. Am. Chem. Soc., I05, 6233-6236, 1983.

Sachse, G. W., R. C. Harriss, J. Fishman, G. F. Hill, and D. R Cahoon, Carbon monoxide over the Amazon Basin during the 1985 dry season, J. Geophys. Res., this issue.

Strickland, J. D. H., Solar radiation penetrating the ocean. A review of requirements, data and methods of measurement, with particular reference to photosynthetic productivity, J. Fish. Res. Bd. Canada $15,453-493,1958$.

$\mathrm{Su}, \mathrm{F}$., J. G. Calvert, and J. H. Shaw, Mechanism of the photooxidation of gaseous formaldehyde, J. Phys. Chem. 83, 3185-3191, 1979.

Tingey, D. T., M. Manning, L. C. Grothaus, and W. F. Burns, The influence of light and temperature on isoprene emission rates from live oak, Physiol. Plant, 47, 112-118, 1979.

Torres, A. L., and H. Buchan, Tropospheric nitric oxide measurements over the Amazon Basin, J. Geophys. Res., this issue.

Wine, P. H., R. J. Atsalos, and R. L. Mauldin, III, Kinetic and mechanistic study of the $\mathrm{OH}+\mathrm{HCOOH}$ reaction, J. Phys. Chem., 89, 2620-2624, 1985 .

Wofsy, S. C., R. C. Harriss, and W. A. Kaplan, Carbon dioxide in the atmosphere over the Amazon basin, J. Geophys. Res., this issue.

Yamamoto, S., and R. A. Back, The photolysis and thermal decomposition of pyruvic acid in the gas phase, Can. J. Chem., 63, 549-554, 1985.

Zimmerman, P. R., R. B. Chatfield, J. Fishman, P. J. Crutzen, and P. L. Hanst, Estimates on the production of $\mathrm{CO}$ and $\mathrm{H}_{2}$ from the oxidation of hydrocarbon emissions from vegetation, Geophys. Res. Let., 5, 679-682, 1978.

Zimmerman, P. R., J. P. Greenberg, and C. E. Westberg, Measurements of atmospheric hydrocarbons and biogenic emission fluxes in the Amazon boundary layer, J. Geophys. Res., this issue.

D. J. Jacob and S. C. Wofsy, Earth and Planetary Sciences, Division of Applied Sciences, Harvard University, Cambridge, MA 02138.

(Received December 18, 1986; revised June 22, 1987; accepted June 23, 1987.) 